\title{
Andrzej Wilk
}

dr hab. inż., prof. uczelni

Politechnika Gdańska

Katedra Inżynierii Elektrycznej Transportu

andrzej.wilk@pg.edu.pl

\section{Cezary Specht}

prof. dr hab. inż.

Uniwersytet Morski w Gdyni

Katedra Geodezji i Oceanografii

c.specht@wn.umg.edu.pl

\section{Władysław Koc}

prof. dr hab. inż.

Politechnika Gdańska

Katedra Transportu Szynowego i Mostów

kocwl@pg.edu.pl

\section{Krzysztof Karwowski}

dr hab. inż., prof. uczelni

Politechnika Gdańska

Katedra Inżynierii Elektrycznej Transportu krzysztof.karwowski@pg.edu.pl

\section{Jacek Skibicki}

dr hab. inż., prof. uczelni

Politechnika Gdańska

Katedra Inżynierii Elektrycznej Transportu jacek.skibicki@pg.edu.pl

\section{Jacek Szmagliński}

dr inż.

Politechnika Gdańska

Katedra Transportu Szynowego i Mostów

jacek.szmaglinski@pg.edu.pl

\section{Paweł Dąbrowski}

dr inż.

Uniwersytet Morski w Gdyni

Katedra Geodezji i Oceanografii

p.dabrowski@wn.umg.edu.pl

\section{Mariusz Specht}

dr inż.

Uniwersytet Morski w Gdyni

Katedra Transportu i Logistyki

m.specht@wn.umg.edu.pl

\section{Marek Zienkiewicz}

dr inż.

Politechnika Gdańska 


\author{
Katedra Geodezji \\ marek.zienkiewicz@pg.edu.pl
}

\title{
Sławomir Judek
}

dr inż.

Politechnika Gdańska

Katedra Inżynierii Elektrycznej Transportu

slawomir.judek@pg.edu.pl

\section{Piotr Chrostowski}

dr inż.

Politechnika Gdańska

Katedra Transportu Szynowego i Mostów

piotr.chrostowski@pg.edu.pl

\section{Marcin Skóra}

mgr inż.

Uniwersytet Morski w Gdyni

Katedra Geodezji i Oceanografii

marcin21@gmail.com

\section{Sławomir Grulkowski}

dr inż.

Politechnika Gdańska

Katedra Transportu Szynowego i Mostów

slawomir.grulkowski@pg.edu.pl

DOI: 10.35117/A_ENG_20_04_01

\section{Determination of the tram track axis using a multi receiver GNSS measurement system}

\begin{abstract}
This article refers to research, that has been conducted by an interdisciplinary research team from the Gdańsk University of Technology and the Maritime University in Gdynia since 2009. These investigation concerns the determination of a railway track axis using the mobile satellite measurement technique. Following the dynamic development of GNSS techniques, that could be seen in the last decade, the team carried out further experiments aimed at developing an effective measurement method. Using the acquired experience in this period, another measurement campaign was carried out on the tram tracks in Gdansk. The main goal of these measurements was to check how the new assumptions regarding the method of mounting the antennas as well as their placement on the measuring platform will work in various field conditions. For this purpose, ten sets of GNSS receivers offered by two independent manufacturers - currently market leaders - were used. The choice of testing track section made it possible to analyze the repeatability of results obtained from multiple measurements in conditions of varying GNSS signal availability. The article presents in a synthetic way the course of this research and the obtained results.
\end{abstract}

Keywords: Tram track; Satellite measurements; Accuracy analysis

\section{Introduction}

The ways of running trains and building and maintaining a railroad developed independently in individual countries and this continued for decades. As a result of this process, there are currently a large number of incompatible power supply systems for vehicles, signaling, 
communication, and guidelines for the design, construction, and diagnostic measurements of tracks.

To remedy this disadvantage, a number of studies have been carried out in Europe for some time to create a common space for rail traffic. As a result of these activities, documents describing the conditions of interoperability of railway infrastructure [22] and rail traffic control [23] as well as standards for modeling the axis of the railway track - design [20] and track condition analysis (ie assessment of track deformation and unevenness) [21] were developed.

This paper focuses on the evaluation of track geometry analysis methods. It consists of the following phases [19]:

- planning a measurement campaign,

- measurements of the track geometry,

- analysis of the obtained results,

- making decisions,

- data archiving.

The currently used measurement techniques used to determine the geometry of the track can be divided, taking into account two premises:

- accuracy in determining parameters (global and local),

- performance of the measurement method (i.e. measurement speed).

In general, it can be assumed that the more time consuming (and expensive) a given measurement method is, the greater the accuracy, both global and local, can be expected [11]. The most accurate methods are static (traditional) methods that use tachometric measurement and measurement of arrows on a specific chord to recreate the local geometric parameters of the track $[8,17-18,28]$. The conducted research focuses on the development of measurement methods that are not inferior in their accuracy to static measurements, with significantly lower time and labor consumption. Such methods mainly rely on the use of GNSS (Global Navigation Satellite System) techniques and the integration of these techniques with other measurement methods [1-2, 4-5, 9-10, 16].

In 2018, the National Center for Research and Development and the company PKP Polskie Linie Kolejowe S.A. awarded the consortium of the Gdańsk University of Technology and the Maritime University of Gdynia with a research project entitled "Development of an innovative method for determining the precise trajectory of a rail vehicle" (POIR.04.01.01-000017 / 17), which assumes the use and further development of the Mobile Satellite Measurement technique. This paper presents the first (pilot) measurement campaign implemented under the project, aimed at checking the adopted technical and organizational assumptions. For logistical reasons, this campaign was carried out on tram tracks.

\section{Technique of Mobile Satellite Measurements}

After the launch of the ASG-EUPOS [3] reference station network in our country in 2008, the interdisciplinary research team of the Gdańsk University of Technology and the Naval Academy in Gdynia came up with the idea of using continuous (mobile) satellite measurements to determine the axis of the railway track [12-13, 15 ]. The Mobile Satellite Measurement Technique, developed over the next many years, consists of carrying out measurements with the help of a moving measurement platform on which high-class GNSS receivers are installed with controllers and additional instruments. The platform may be selfpropelled, but it is not required, therefore, a motorized railway or tram vehicle was used during the research. The platform may be pulled by such a vehicle (which is the recommended solution) or pushed.

During the first measurements, made in 2009 on the section of the Kościerzyna Kartuzy railway line [12], a measuring set was used, which consisted of the following elements: 
- motor vehicle - EM-15 draisine,

- measuring vehicle - two-axle PWM-15 wagon,

- measuring instruments - 4 Leica ATX 1230GG GNSS receivers.

In the following years, various configurations of the arrangement of measuring devices were tested, as well as models of GNSS receivers of an increasingly higher class [14, 24-27].

Many sections were measured several times in order to check the repeatability of the measurement performed. A summary of the configurations of the measurement devices used is shown in Figure 1. To increase the efficiency of the Mobile Satellite Measurement method, the measurement should be carried out with the highest possible frequency of determining the position - currently, it is a maximum of $20 \mathrm{~Hz}$. The analysis of measurement data led to the conclusion that the driving speed should be such that the distance between the measurement points was not greater than $0.5 \mathrm{~m}$.

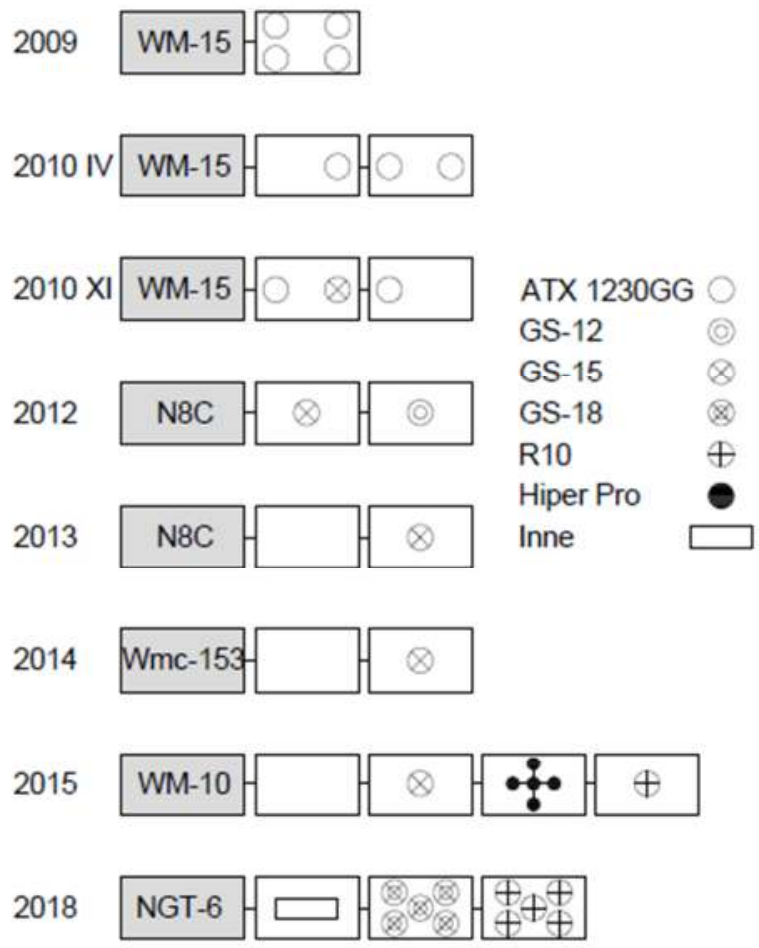

1. Diagram of the arrangement of GNSS receivers and accompanying devices in individual measurement campaigns in 2009-2018

\section{Planning the presented measurement campaign - selecting the location of measurements and the rail vehicle}

The planned measurement had to be performed in conditions as close to the real ones as possible (i.e. those prevailing on railway lines), hence it was necessary to use an appropriate rail vehicle. Due to the complicated (and time-consuming) procedure of gaining access to the railway network, as well as the significant cost of the railway vehicles used, it was decided to conduct a measurement campaign inaugurating the project in a tram track, using a tram vehicle. Thanks to the courtesy of the Gdańskie Autobusy i Tramwaje company, which provided the measuring vehicle with the service, it was possible to start planning further elements of the measurement campaign.

Performing the test measurement, it was necessary to examine the influence of the tram line surroundings, the track condition, and its geometrical shape on the obtained measurement signal. For this reason, it was necessary to use a fragment of the tram network consisting of the most diverse sections possible. Additionally, it was decided to perform measurement repeatability tests. This meant that the measuring distance was not too long so 
that it could be measured multiple times during one measuring session. It was also necessary to minimize any maneuvering works that would increase the test time and, consequently, could create difficulties in testing the repeatability of measurements.

Ultimately, the testing ground for kinematic measurements of tram tracks was the existing tramway in the Gdańsk district of Brzeźno, which forms the layout of the so-called street loop with a length of about $3 \mathrm{~km}$. The use of such a track system made it possible to perform repeatable measurements without the need to perform maneuvers at limit switches or junctions. The location plan of the measurement sections is shown in Fig. 2. The individual measurement sections differ from each other in the condition of the rail surface and the presence of different horizon screens. The measurements are planned on the following sections related to the course of the road system:

a) the $850 \mathrm{~m}$ long section of Aleja Generała Józefa Hallera, starting at the end of Pętla Brzeźno Plaża (located near the intersection of Aleja Generała Józefa Hallera and Wyszne street) and ends at the intersection with Aleja Macieja Płażyńskiego,

b) the $400 \mathrm{~m}$ long section of Aleja Macieja Płażyńskiego between the intersection with Aleja Generała Józefa Hallera and the intersection with Gdańska Street,

c) Gdańska Street along its entire length, approximately $1000 \mathrm{~m}$ from the intersection with Aleja Macieja Płażyńskiego to the intersection with Ignacego Krasickiego and Waleczne Street,

d) a turning track at the end of Pętla Brzeźno and the section between Pętla Brzeźno and Mazurska Street (tramway running regardless of the road system) with a length of approximately $150 \mathrm{~m}$,

e) along the entire length of Mazurska Street, approximately $330 \mathrm{~m}$ from the junction with South Street to the junction with Dworska Street,

f) the independent section of the road system between Dworska Street and Krańcówka Pętla Brzeźno Plaża, approximately $270 \mathrm{~m}$ long.

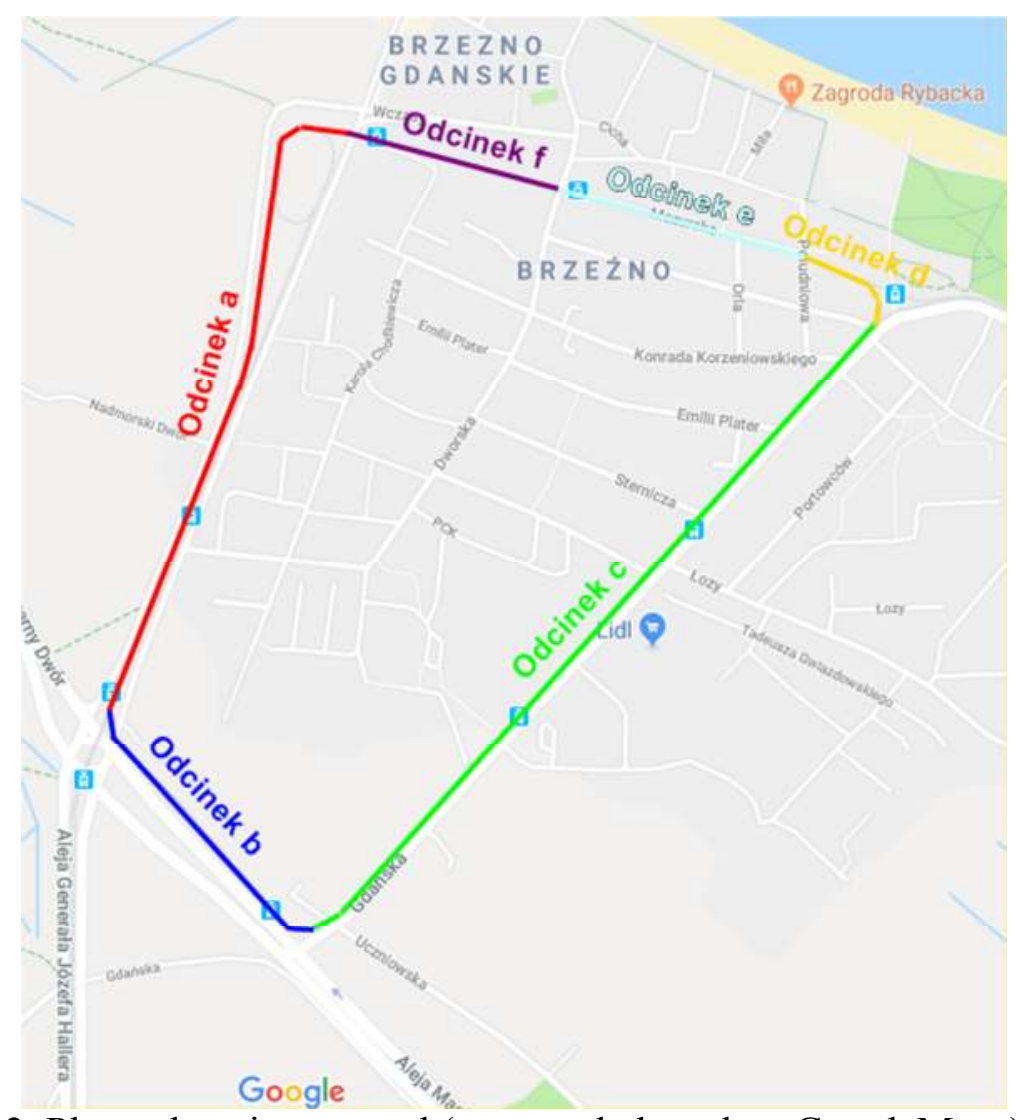

2. Planned testing ground (own study based on GoogleMaps) 
Sections $a$ and $b$ are characterized by a small number of terrain barriers (single trees near the track) and a very good technical condition of the track. They were selected as reference ones, enabling the analysis of the influence of the track condition and its surroundings on the accuracy of the measurements. The condition of the track surface and the distance from the track axis to the existing terrain obstacles on the section a is shown in Figure 3.

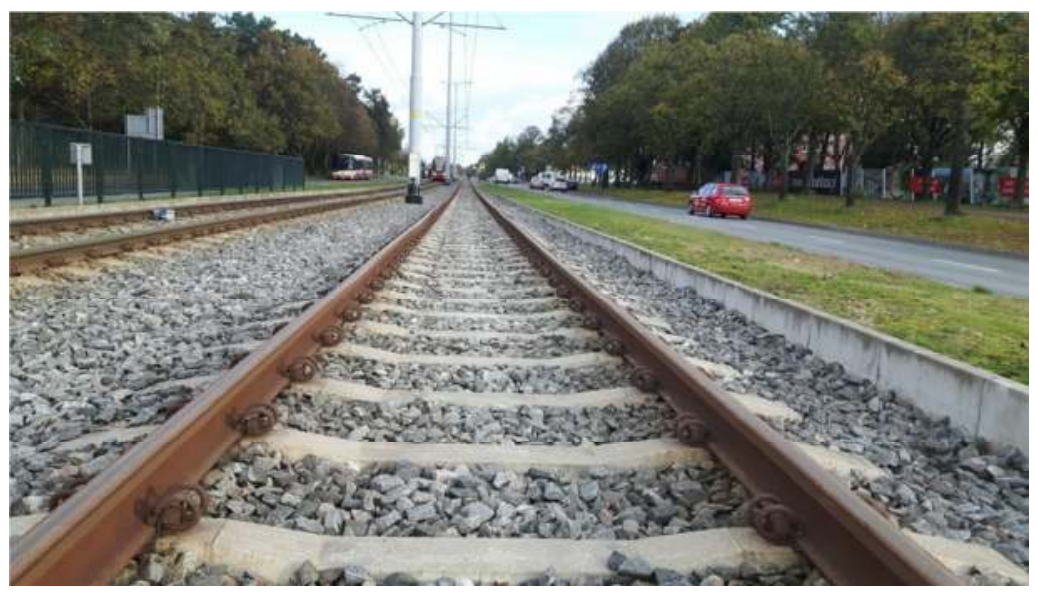

3. The condition of the track and terrain obstacles on the section $a$

Section $c$ is characterized by a greater number of terrain barriers than in the previous sections (clumps of trees and buildings located along the track) and a very poor technical condition of the surface (high values of twist and track unevenness in both planes). This section was selected as the section to study the influence of the track condition on the measurement accuracy. The condition of the rail surface and the distance from the track axis to the obstacles along section $c$ are shown in Figure 4.

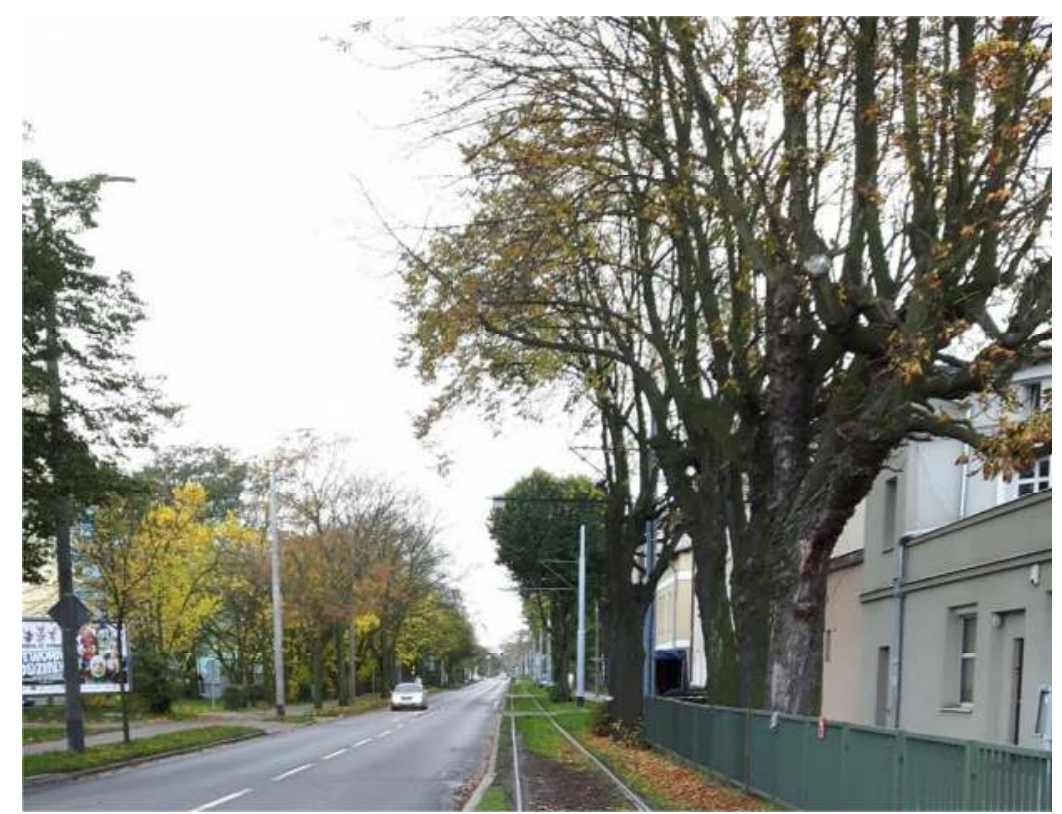

4. The condition of the track and terrain obstacles along the section $c$

Sections $d$ and $e$ are characterized by a very high intensity of field barriers (trees with crowns located above the tram track and tall buildings directly adjacent to the tram track along the entire length of the section) and a good condition of the track. These sections were selected to study the effect of field barriers on measurement accuracy. The condition of the 
track surface and the distance from the track axis to the obstacles along the section $\mathrm{d}$ are shown in Figure 5.

Section $f$ is characterized by an average number of field barriers (clumps of trees and buildings located along the track) and a good condition of the track. This episode was chosen as the reference for episode $c$.

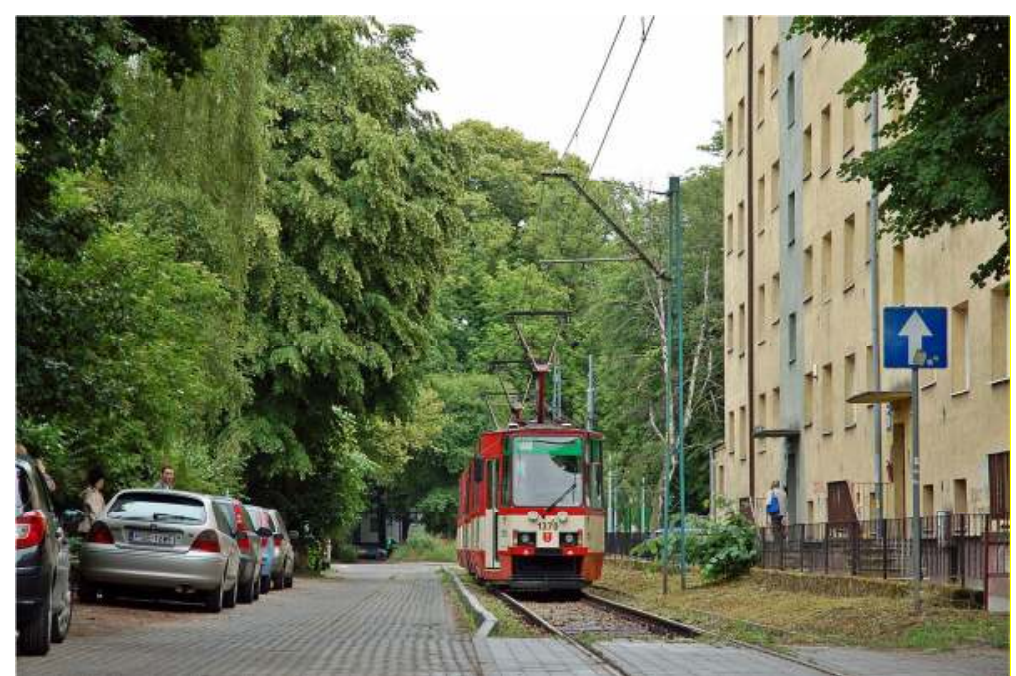

5. The condition of the track and obstacles along the section $d$

\section{Measurement team}

One of the objectives of the measurement campaign was also to test the quality and stability of the GNSS antenna stands designed by the Team in motion conditions. For this reason, the measuring wagons had to be of a construction comparable to that of the platform wagon operated by the Polish State Railways. The most important criterion was the flat structure of the measuring platform on which the transverse mounting beams were to be supported. Ultimately, three bogies were selected from the pre-war DWF 300 series carriages, also owned by the Gdańsk Buses and Trams company. After the wagon body was scrapped, they were used for the transport of paving materials, therefore their upper surfaces were built like a platform wagon. A set of several carriages selected for the measuring assembly is shown in Figure 6.

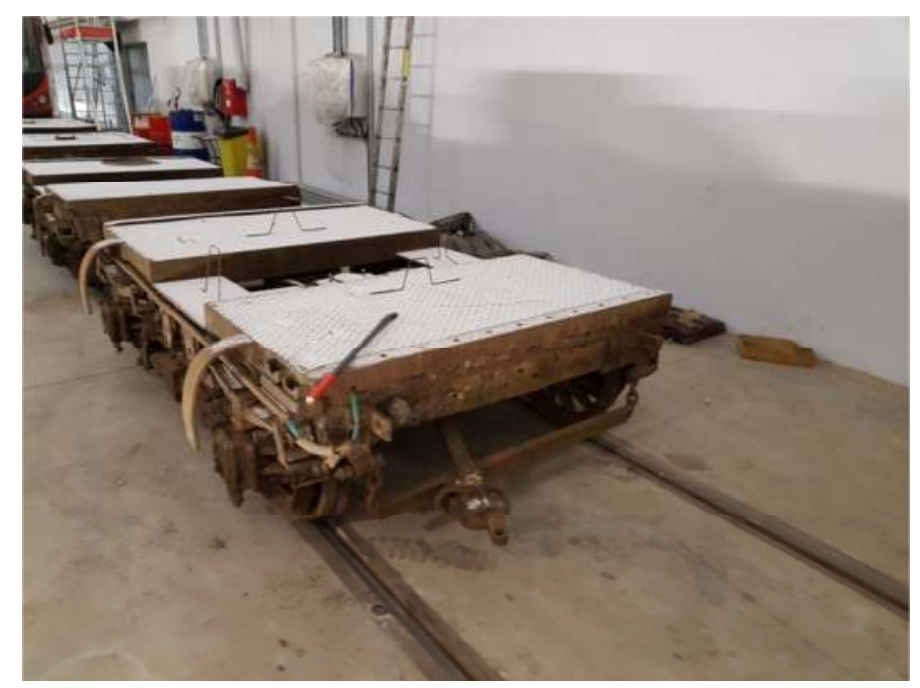

6. Bogies of a GWF 300 series wagon used as measuring vehicles 
Due to the fact that the DWF 300 bogies do not have their own drive, it was necessary to choose a railcar that would meet the following assumptions:

- the possibility of continuous driving at a constant, low speed (only new tram vehicles equipped with a semiconductor drive system have this option),

- possibility of supplying measuring devices and recording computers from the on-board $230 \mathrm{~V}$ T network (this is possible in new tram vehicles but only the Bombardier NGT-6 car has a classic socket in a convenient location).

Thus, the selected measuring unit was to consist of no less than three measuring carriages attached to the NGT-6 tram (Fig. 7). On the first car from the motor vehicle side, it was decided to install accelerometers, inclinometers, and a GNSS compass. On the next two, due to the lower impact of the horizon obstructions resulting from the presence of a highpowered tram, it was decided to install 10 GNSS receivers.

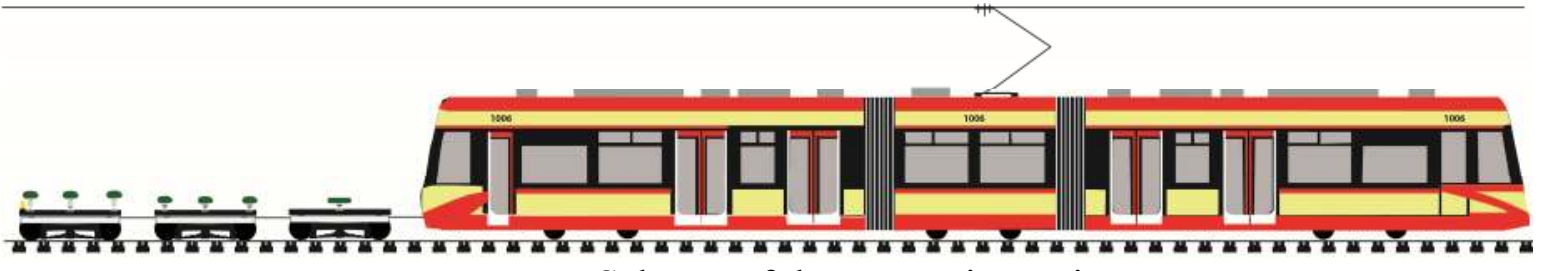

7. Scheme of the measuring train

The assumption of the research project is to use GNSS receivers to determine the geometric parameters of the railway track. One of the goals of the work is to improve the accuracy of determining the coordinates of the railway track based on the known spatial configuration of the GNSS receivers used. By introducing specific geometrical conditions in the measurement methodology, it is possible to obtain additional determinations of the track axis position. In the case of measurements using trams and five GNSS receivers installed on each of them, a square-shaped geometric structure was used. The central receiver is placed above the bogie of the trolley with a precise tachometric method. The remaining four receivers were placed at the vertices of the square whose diagonals intersected over the bogie pivot. As a result, it was possible to determine spatial constants between the apparatus, unchanged throughout the duration of the measurement.

The determined distances were used in the later process of developing the measurement data. The coordinates of the GNSS receivers calculated for each measurement epoch were affected by an error of unknown value. Taking into account the constant geometrical conditions of the measurement structure, it was possible to formulate a system of linear equations for each measurement epoch. The parameters in the process of geodetic alignment of observations were the coordinates of the GNSS receivers. The calculations used, inter alia, a parametric method with conditions binding parameters [6]. The obtained parameter estimators took into account known spatial relationships between receivers. Thus, the obtained results were more reliable than the measurement of the axis of the railway track with the use of a single GNSS receiver.

\section{Apparatus and assembly of the measuring system}

A total of 10 GNSS receivers were used to measure the position of mobile platforms: five Leica Viva GS-18 antennas and five Trimble R10 antennas [7]. GNSS receivers mounted on racks are shown in Figure 8, while Figure $\mathbf{9}$ shows a diagram of the arrangement and numbering of individual antennas. The receivers with the controllers are located on specially designed supporting structures adapted to the installation of tribrachs. The racks were made in such a way that the tribrachs had degrees of freedom in the horizontal plane, thanks to which it was possible to create the assumed spatial configuration of all receivers. 


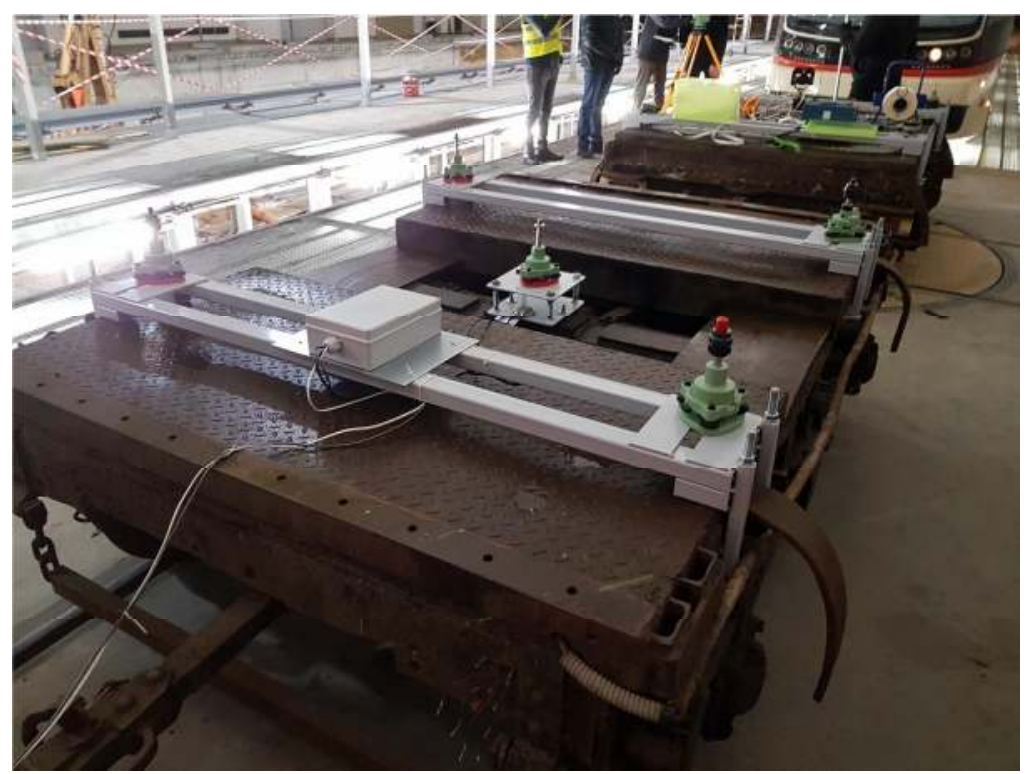

8. Assembly of racks (with tribrachs) on measuring bogies - Tram Depot Wrzeszcz

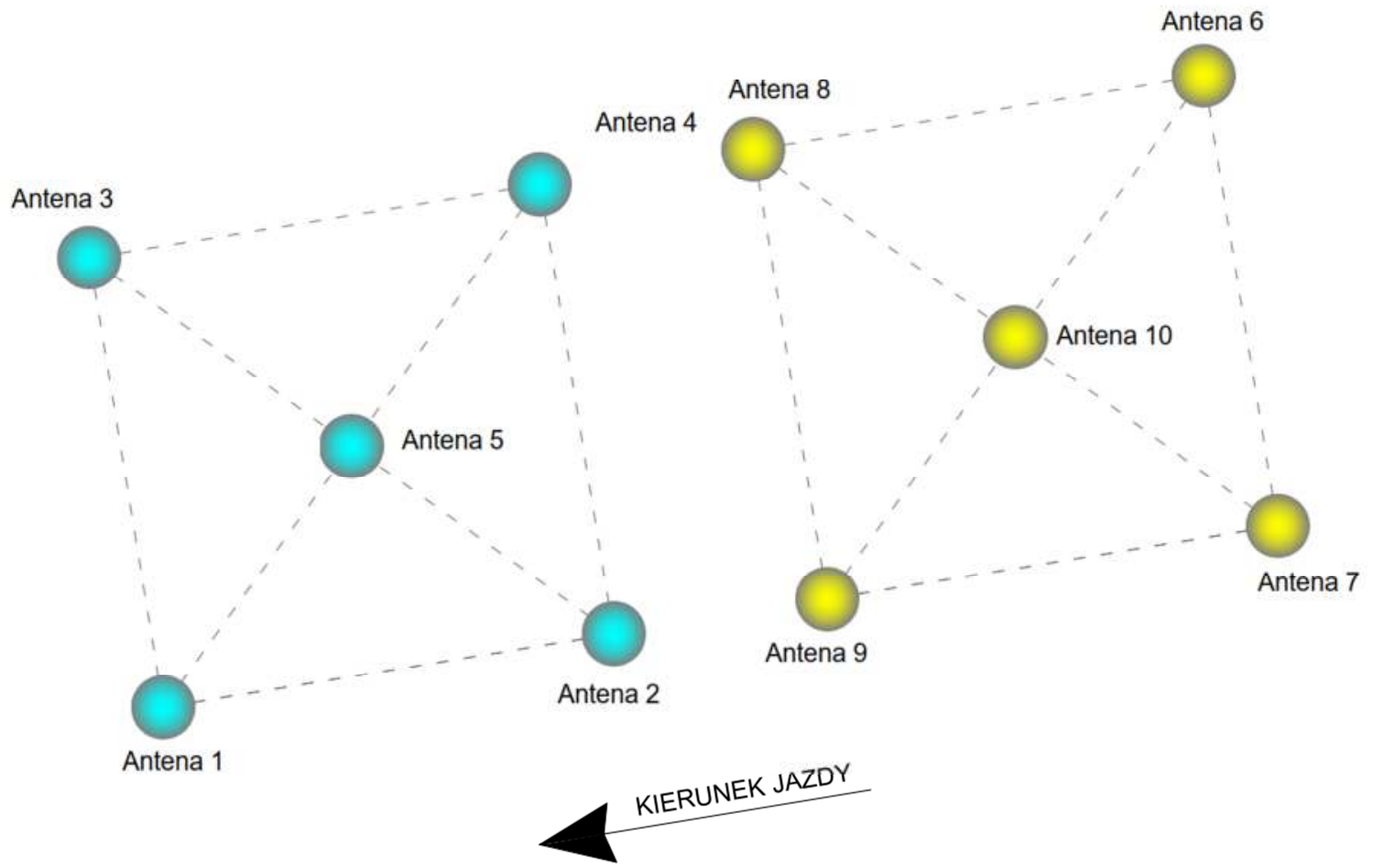

9. Arrangement of the Leica Viva GS-18 receivers (1-5 antennas) and Trimble R10 (610 antennas) on tram bogies

Preliminary work as part of the preparation of the measurement campaign concerned the exact dimensioning of the 300 series trucks in order to adapt the GNSS receiver mounting system to their dimensions.

Accelerometers, an inclinometer, and a GNSS compass are mounted on the first bogie of the 300 series, located directly behind the motor tram. Accelerometric and inclinometric measurements were recorded by an independent system synchronized with the GNSS module. These measurements were to provide information about the dynamic phenomena occurring on the towed bogies during the measurement. Figure $\mathbf{1 0}$ shows the control units for accelerometric measurements. 


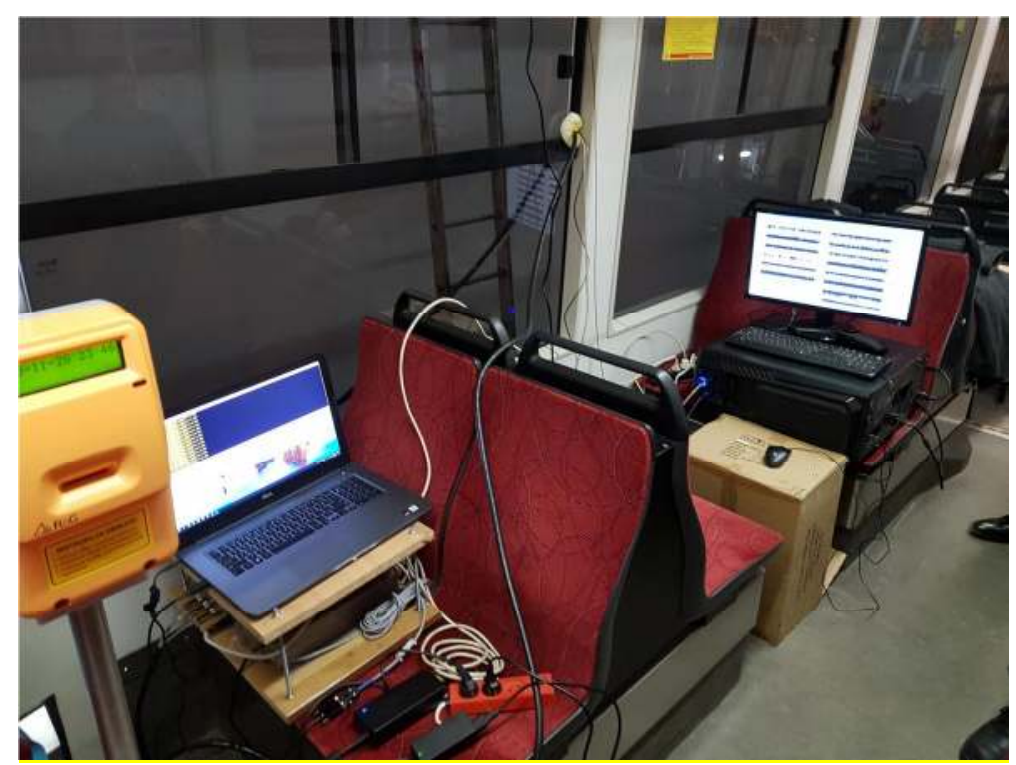

10. Accelerometer and inclinometer system and GNSS compass controllers

\section{Measurements}

Around 11.00 p.m. the assembly and calibration of the measuring instruments was completed, carried out in the Wrzeszcz Tram Depot. Then the measuring train went towards Brzeźno, where the measuring range was located. During the trip, it was noticed that the operation of traction inverters generates a strong electromagnetic field that disturbs the cable communication between the measuring devices and the recorder (PC). It was then decided to manually turn off the traction inverter No. 2 in the tram, thanks to which it became possible to register all the assumed parameters, while the traction vehicle power, reduced by half, was still sufficient to conduct measurements.

The installation of the satellite receivers on the tribrachs and the switching on of the controllers took place after the measurement set had reached the area of the test site - in Brzeźno (Fig. 11). Between midnight and 03:38 am, 6 full measurement rides were made along the designated route. The first two rides were made with a constant speed of the measuring train not exceeding $10 \mathrm{~km} / \mathrm{h}$. The next two runs were made at a constant speed not exceeding $20 \mathrm{~km} / \mathrm{h}$, and the last two rides were made at a constant speed not exceeding 30 $\mathrm{km} / \mathrm{h}$. In total, over $18 \mathrm{~km}$ of tracks were measured, and the results of these measurements were used to determine the accuracy and reliability of the measurement method used. Figure 12 shows the measurement results in the form of the positions of the approach route and the measuring range plotted on the orthophotomap. 


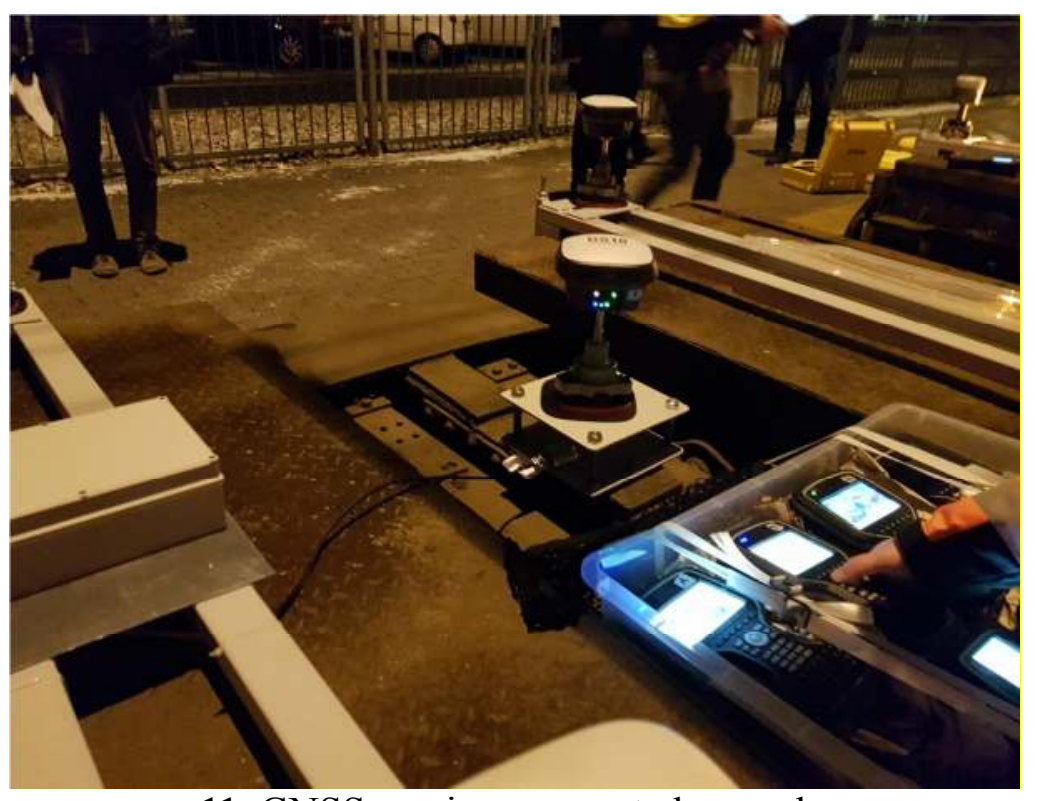

11. GNSS receivers mounted on racks

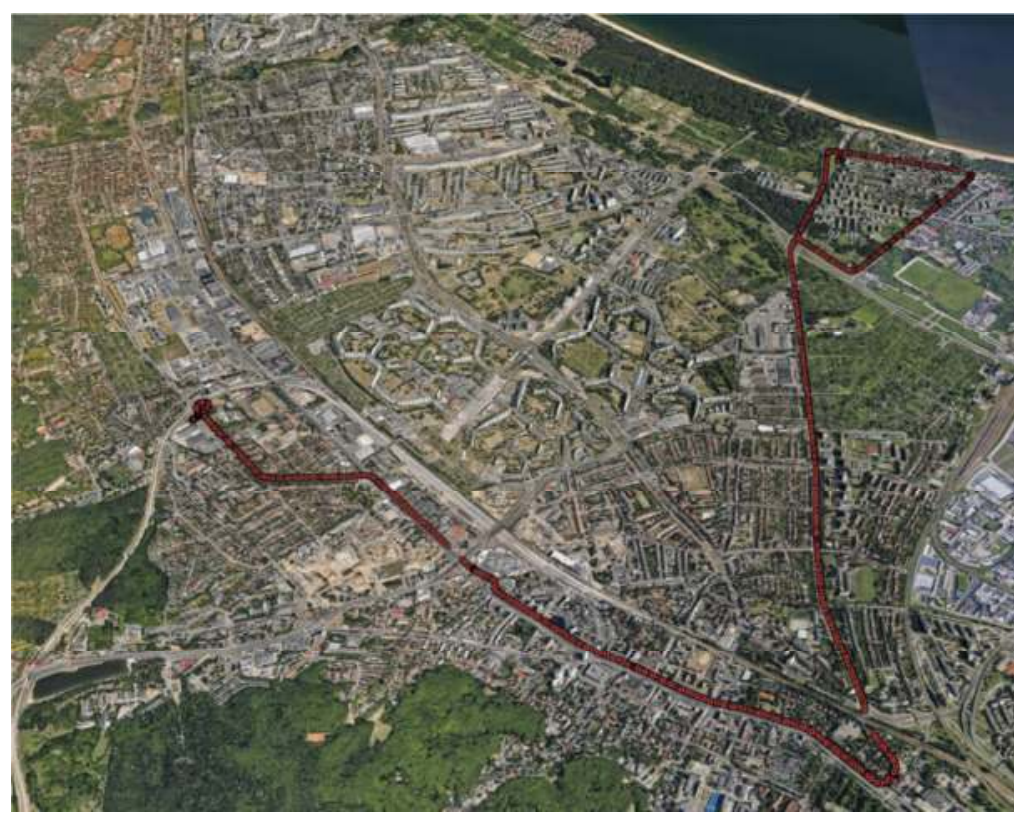

12. Measured fragments of tramways in Gdańsk (the GoogleEarth application was used for visualization)

\section{Measurement results}

During the measurement campaign, 6 measurement rides were made along the designated route - a large street loop in Brzeźno with the use of ten GNSS receivers (5 Leica Viva GS-18 antennas and 5 Trimble R10 antennas). The receivers worked in the following configurations:

- 2 rides in GPS constellation tracking mode; the rides took place between 00:09 and 00:52,

- 2 rides in the GPS, GLONASS and Galileo constellation tracking mode; the rides took place between 00:58 and 01:42,

- 2 rides in GPS and GLONASS constellation tracking mode; the rides took place between 01:42 and 02:23.

The ending session was carried out on the way back from Brzeźno to Zajezdnia Wrzeszcz with the use of 1 receiver set in the GPS + GLONASS constellation tracking mode. He made this journey between 03:37 and 04:32; 65,645 items were registered then. 
Table 1 shows the number of registered data sets depending on the configuration in which multi-system GNSS receivers worked. The individual columns show the number of position determinations that meet the established accuracy criteria - uncertainty radius not greater than $20 \mathrm{~cm}$. Each column represents the measurement route traveled twice. The diversified number of recorded data resulted from many factors, such as the different operating conditions of the receivers (location on the platform), the different intervals of the receivers' operation time (servicing the controllers), the arbitrary assumption of the cut-off level, etc.

Tab. 1. Number of position calculations obtained from individual GNSS receivers (antenna markings as in Figure 10)

\begin{tabular}{|c|c|c|c|}
\hline Receiver number & GPS & GPS+GLO+Gal & GPS+GLO \\
\hline Antenna 1 & 39658 & 39950 & 55627 \\
Antenna 2 & 40651 & 48077 & 45369 \\
Antenna 3 & 38800 & 39097 & 55918 \\
Antenna 4 & 40005 & 38671 & 58935 \\
Antenna 5 & 40943 & 40224 & 58110 \\
Antenna 6 & 37499 & 31988 & 47171 \\
Antenna 7 & 36887 & 31881 & 46629 \\
Antenna 8 & 30876 & 31895 & 44753 \\
Antenna 9 & 39154 & 32273 & 47096 \\
Antenna 10 & 37086 & 30270 & 46802 \\
\hline
\end{tabular}

The selected test site and the geometry of the positioning of the receivers resulted in significant differences in the number of satellites being tracked. This affected the calculated values of the precision parameters in the form of DOP (Dilution of Precision) coefficients. The DOP geometric coefficients define the spatial arrangement formed by the GNSS receiver and the satellites from which the receiver received the signal. Based on the determined distances to the satellites and the known coordinates of the satellites, it is possible to determine the position of the receiver. This task is a classic backward spatial indentation, commonly used in geodetic calculations. After taking into account the transition from the geocentric to the topocentric system, the values of the geometric coefficients related to HDOP (Horizontal Dilution of Precision) coordinates, VDOP (Vertical Dilution of Precision) elevation coordinates and TDOP (Time Dilution of Precision) receiver clock error. From these three obtained coefficients, two basic coefficients are determined: spatial PDOP (Position Dilution of Precision) and geometric GDOP (Geometric Dilution of Precision).

The values of the HDOP and PDOP geometric coefficients are related to the error value of the position determined by the receiver. The dependence of the error and the geometric coefficient is directly proportional. On the other hand, the value of the geometric coefficient, in terms of spatial geometry, is related to the volume of the solid formed during the measurement epoch by the satellites and the receiver. The value of the geometric coefficient PDOP is the smaller the larger the volume of the subject solid. The even distribution of satellites on the celestial hemisphere favors obtaining more favorable values of geometric coefficients, and, consequently, lowering the positioning error by the receiver. 
Table 2 shows the change in the PDOP value and the average visible number of satellites using the GPS system and the combination of GPS and Glonass systems for the selected measurement platform. This measure is not unambiguous, but it is assumed that the PDOP coefficient values at the level of $2 \div 5$ are the values indicating the high quality of GNSS positioning (ideal level PDOP = 1). As shown in Table 2, from the point of view of accuracy, the obtained PDOP values of 2.38 for the GPS / GLONASS configuration indicate good measurement conditions and the possibility of using the obtained results for positioning the track axis.

Tab. 2. Obtained PDOP values and the visible number of satellites

\begin{tabular}{|l|c|c|c|c|c|c|c|c|c|c|c|c|}
\hline & \multicolumn{7}{|c|}{ GPS } & \multicolumn{7}{c|}{ GPS/GLONASS } \\
\hline Receiver & 1 & 2 & 3 & 4 & 5 & $\begin{array}{c}\text { aver } \\
\text { age }\end{array}$ & 1 & 2 & 3 & 4 & 5 & $\begin{array}{c}\text { aver } \\
\text { age }\end{array}$ \\
\hline $\begin{array}{l}\text { Average } \\
\text { PDOP } \\
\begin{array}{l}\text { Minimu } \\
\text { m PDOP } \\
\text { Average } \\
\text { number } \\
\text { of } \\
\text { satellites }\end{array}\end{array}$ & 2,41 & 2,5 & 3,37 & 2,39 & 2,36 & 2,61 & 2,51 & 2,2 & 2,7 & 2,21 & 2,26 & 2,38 \\
\hline
\end{tabular}

The designated coordinates of the track axis enable the visualization of the measured route on the PL-2000 coordinate grid. Figure 13 shows the axis positions of the tram track recorded by all receivers during 6 runs along the Brzeźno street loop. It should be noted, however, that there are in fact 3 trajectories of the moving antennas which correspond to the location of these antennas on the carts. One trajectory (middle) is marked by 2 antennas on turning pivots, the second by 4 antennas on the left side of the measuring train, and the third by 4 antennas on the right side of the train. Since the distances between these trajectories are relatively small, the applied scale of the drawing does not allow to reveal the differences. These differences can be observed by increasing the spatial configuration of receivers in selected parts of the route. Figure $\mathbf{1 4}$ shows the measurement situation in the area of the junction on the Brzeźno Plaza tram loop.

Thanks to multiple journeys of the same section (in different measurement conditions), it became possible to analyze the repeatability of recreating straight sections of the route. The positions recorded by ten receivers were treated as independent measurements, which, based on the known antenna configuration, were reduced to one common axis of the track (through appropriate projection). As a result of such an operation, for each straight section, 60 sets of coordinates were obtained, determining the appropriate least-squares lines. Figure 15 shows the result of the relevant analysis in the form of simple least-squares plots for a selected line segment. Analogous charts for the remaining sections give a similar picture of the situation. They show that the reconstruction of the track axis in favorable conditions for GNSS measurements (for PDOP <2) was characterized by the uncertainty of $\pm 1 \mathrm{~cm}$, which proves the high quality of the measurements. 


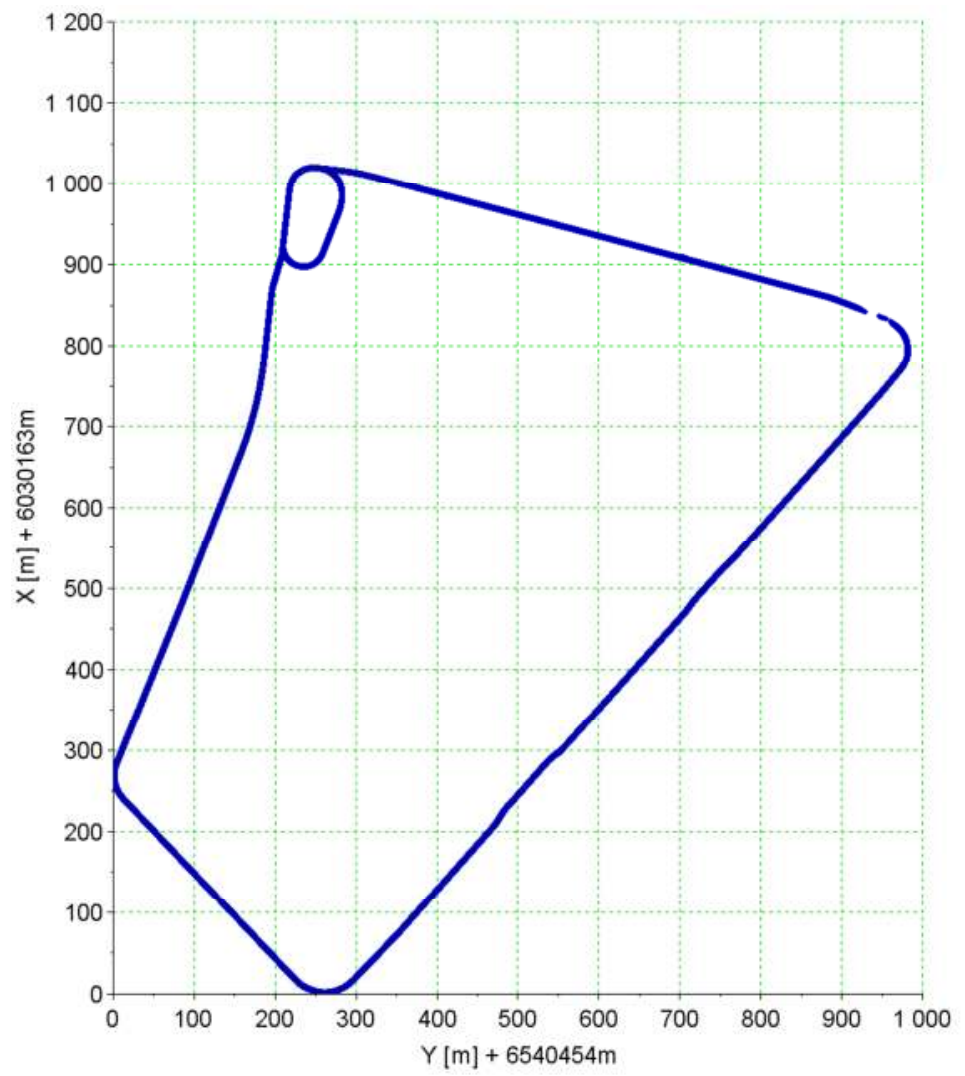

13. Visualization of the measured fragment of tram roads in the area of the Brzeźno district in Gdańsk

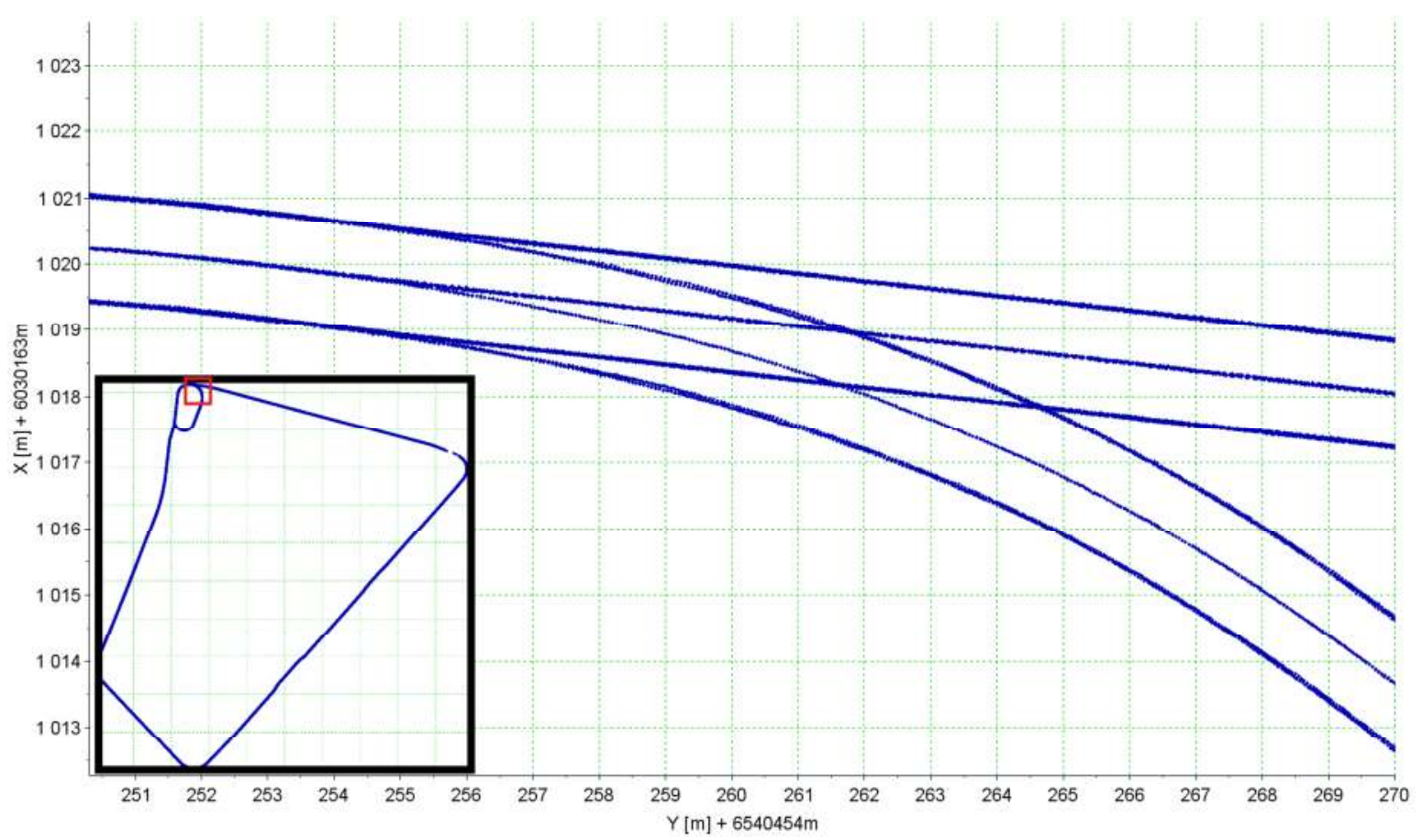

14. Visualization of the measured turnout on the Brzeźno Plaża tram loop (enlarged) 


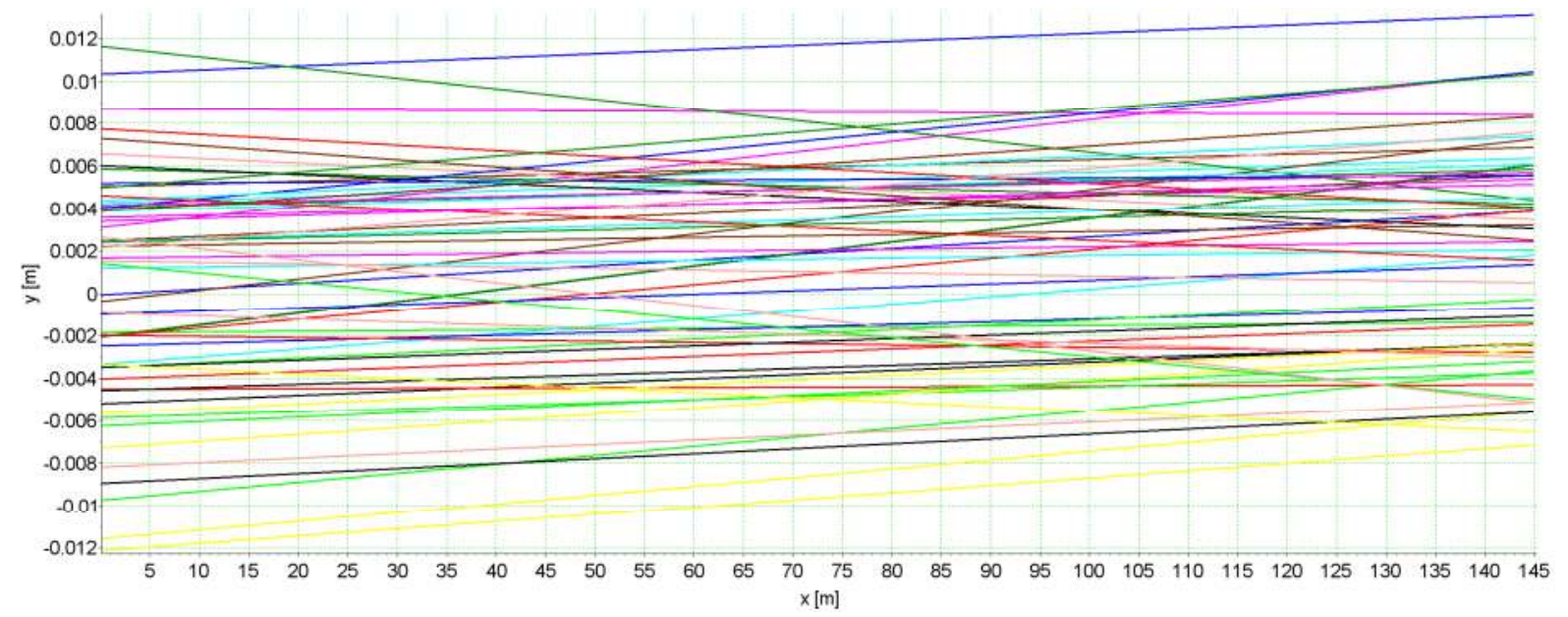

15. List of simple least-squares determined on the basis of multiple runs of the measuring set along the same section of the measured route (on a contaminated scale).

Colors: antenna 1 - black, 2 - blue, 3 - green, 4 - teal, 5 - red, 6 - purple, 7 - yellow, 8 dark green, 9 - brown, 10 - pink

\section{Summary}

The article presents an example of the application of the Mobile Satellite Measurements method to determine the position of the axis of a tram track in the global system of spatial references. Work on the development of this method, which has been going on for over a decade, prompted the authors to carry out tests enabling the assessment of the repeatability of the obtained results in specific measurement conditions. The system of ten GNSS receivers, mounted on a square plan (on two bogies), was to enable the verification of the measurement uncertainty of individual coordinates, and, consequently, also of the reconstructed geometric system.

The selected test site and the geometry of the satellite receivers' positioning resulted in significant differences in the number of satellites being tracked. This influenced the calculated values of the precision parameters in the form of DOP coefficients. From the point of view of accuracy, the obtained values of the PDOP spatial coefficient of 2.38 for the GPS/GLONASS configuration indicate good measurement conditions and the possibility of using the obtained results for positioning the track axis.

Thanks to multiple journeys of the same section (in different measurement conditions), it became possible to analyze the repeatability of recreating straight sections of the route. For each straight line segment, 60 sets of coordinates were obtained, determining the appropriate least-squares lines. On this basis, it was found that the reconstruction of the track axis in favorable conditions of GNSS measurements (for PDOP <2) was characterized by the uncertainty of $\pm 1 \mathrm{~cm}$, which also proves the high quality of the measurements.

In addition, in the presented measurement campaign, the use of inclinometric and accelerometric measurements was tested, enabling the dynamic assessment of the measurement system at different tram speeds.

\section{Acknowledgements}

The authors would like to thank the company Gdańskie Autobusy i Tramwaje for making these measurements possible.

\section{Funding}

The work was carried out as part of the research project "Development of an innovative method for determining the precise trajectory of a rail vehicle" InnoSatTrack (POIR.04.01.0100-0017 / 17), financed by NCBiR and PKP PLK SA. 


\section{Source materials}

[1] Akpinar B., Gulal E.: Multisensor railway track geometry surveying system. IEEE Transactions on Instrumentation and Measurement 2011, Vol. 61, No. 1, pp. 190-197.

[2] Arastounia M., Oude Elberink S.: Application of template matching for improving classification of urban railroad point clouds. Sensors 2016, Vol. 16, No. 12, pp. 3-18.

[3] Baran L. W., Oszczak S., Zieliński J. B.: Wykorzystanie technik kosmicznych w geodezji i nawigacji w Polsce. Nauka 2008, Nr 4, s. 43-63.

[4] Chen Q., Niu X., Zhang Q., Cheng Y.: Railway track irregularity measuring by GNSS/INS integration. The Journal of the Institute of Navigation 2015, Vol. 62, No. 1, pp. 83-93.

[5] Chun L., Nan L., Hangbin W., Xiaolin M.: Detection of High-Speed railway subsidence and geometry irregularity using terrestrial laser scanning. Journal of Surveying Engineering 2014, Vol. 140, Iss. 3, pp. 1-18.

[6] Czaplewski K., Specht C., Dąbrowski P., Specht M., Wiśniewski Z., Koc W., Wilk A., Karwowski K., Chrostowski P., Szmaglński J.: Use of a least squares with conditional equations method in positioning a tramway track in the Gdansk agglomeration. TransNav - the International Journal on Marine Navigation and Safety of Sea Transportation 2019, Vol. 13, No. 4, pp. 895-900.

[7] Dąbrowski P., Specht C., Koc W., Wilk A., Czaplewski K., Karwowski K., Specht M., Chrostowski P., Szmagliński J. Grulkowski S.: Installation of GNSS receivers on a mobile platform - methodology and measureent aspects. Scientific Journals of the Maritime University of Szczecin 2019, Vol. 60, Iss. 132, pp. 18-26.

[8] DB Netz AG, 883.2000 DB_REF-Festpunktfeld.

[9] Gao Z., Ge M., Li Y., Shen W., Zhang H., Schuh H.: Railway irregularity measuring using Rauch-Tung-Striebel Smoothed Multi-Sensors Fusion System: Quad-GNSS PPP, IMU, Odometer, and Track Gauge. GPS Solutions 2018, Vol. 22, No. 2, pp. 1-14.

[10] Gikas V., Daskalakis S.: Determining rail track axis geometry using satellite and terrestrial geodetic data. Survey Review 2008, Vol. 40, No. 310, pp. 392-405.

[11] Glaus R.: The Swiss Trolley - A Modular System for Track Surveying. Geodätischgeophysikalische Arbeiten in der Schweiz, Akademie der Naturwissenschaften Schweiz, 2006.

[12] Koc W., Specht C., Jurkowska A., Chrostowski P., Nowak A., Lewiński L., Bornowski M.: Określanie przebiegu trasy kolejowej na drodze pomiarów satelitarnych. II Konferencja Naukowo-Techniczna „Projektowanie, Budowa i Utrzymanie Infrastruktury w Transporcie Szynowym INFRASZYN 2009”, Zakopane, 22-24 kwietnia 2009, s. 170-187.

[13] Koc W., Specht C.: Selected problems of determining the course of railway routes by use of GPS network solution. Archives of Transport 2011, Vol. 23, iss. 3, pp. 303-320.

[14] Koc W., Specht C.: Wybrane problemy wyznaczania przebiegu trasy kolejowej z wykorzystaniem rozwiązań sieciowych GPS. Logistyka 2010, $\mathrm{Nr}$ 4, s. 1-13.

[15] Koc W., Specht C.: Wyniki pomiarów satelitarnych toru kolejowego. TTS Technika Transportu Szynowego 2009, Nr 7-8, s. 58-64.

[16] Li Q., Chen Z., Hu Q., Zhang L.: Laser-Aided INS and Odometer Navigation System for subway track irregularity measurement. Journal of Surveying Engineering 2017, Vol. 143, Iss. 4.

[17] NR/L2/TRK/3201_Network Rail - Management of Tight Clearances and Track Position, Network Rail 2010.

[18] PKP PLK: Standard Techniczny „O organizacji i wykonywaniu pomiarów w geodezji kolejowej" GK-1, Warszawa 2015.

[19] PKP PLK: Warunki techniczne utrzymania nawierzchni na liniach kolejowych Id-1, Warszawa 2005. 
[20] PN-EN 13803 Railway applications - Track - Track alignment design parameters Track gauges $1435 \mathrm{~mm}$ and wider.

[21] PN-EN 13848 Railway applications - Track - Track geometry quality.

[22] Rozporządzenie Komisji (UE) nr 1299/2014 z dnia 18 listopada 2014 r. dotyczące technicznych specyfikacji interoperacyjności podsystemu „Infrastruktura” systemu kolei w Unii Europejskiej.

[23] Rozporządzenie Komisji (UE) 2016/919 z dnia 27 maja 2016 r. w sprawie technicznej specyfikacji interoperacyjności w zakresie podsystemów „Sterowanie” systemu kolei w Unii Europejskiej.

[24] Specht C., Koc W., Chrostowski P., Szmagliński J.: Accuracy assessment of Mobile Satellite Measurements in relation to the geometrical layout of rail tracks. Metrology and Measurement Systems 2019, Vol. 26, Iss. 2, pp. 309-321.

[25] Specht, C.; Koc, W.; Chrostowski, P.; Szmagliński: J. The analysis of tram tracks geometrical layout based on Mobile Satellite Measurements. Urban Rail Transit 2017, Vol. 3, Iss. 4, pp. 214-226.

[26] Specht C., Koc W., Szmagliński J., Gajdzica P., Specht M.: GNSS inventory of historic narrow-gauge railway line in Koszalin under extremely unfavorable measurements conditions from the point of view of satellite signals availability. Proceedings of the $1 \mathrm{st}$ International Conference on Innovative Research and Maritime Applications of Space Technology IRMAST 2015, Gdańsk: Gdańsk University of Technology, 2015, pp. 3-8.

[27] Specht C., Dąbrowski P., Specht M., Koc W., Chrostowski P., Szmagliński J., Dera M., Skóra M.: Mobilne pomiary satelitarne na liniach Pomorskiej Kolei Metropolitalnej. Przegląd Komunikacyjny 2016, Rok 71, Nr 5, s. 9-16.

[28] T HR TR 13000 ST, Railway Surveying, Version 1.0, 2016. 